\title{
Papers
}

\section{Detailing to prevent water-related problems in the building envelope}

Received (in revised form): 21st November, 2006

\begin{abstract}
Justin Henshell FAIA
is a partner in Henshell and Buccellato Consulting Architects in Red Bank, New Jersey, and was the 2000 recipient of the Walter C. Voss Award by the American Society for Testing and Materials. He has received the award for distinguished contributions to knowledge in the field of architecture and building technology, particularly the performance of roofing and waterproofing systems, through more than 30 years of outstanding leadership and dedicated service to the industry. As a consulting architect in the field of moisture-related problems in the building envelope, he prepares and oversees the preparation of construction documents for roofing and waterproofing and masonry systems. He also serves as a consultant on these systems to more than 60 architectural firms throughout the country. He is the author of 'The Manual of Below-Grade Waterproofing Systems', which covers materials and systems for underground and plaza waterproofing.
\end{abstract}

Correspondence: Justin Henshell, Henshell and Buccellato Consulting Architects, 2 Harding Road, Red Bank, New Jersey 07701-2016, USA; Tel: +1(732) 530-4734; Fax: +1(732) 747-8099; E-mail: justin.henshell@verizon.net

\begin{abstract}
Water-related problems in the building envelope can frequently be traced to design details or the use of inappropriate materials, rather than substandard workmanship or materials. It often stems from the designer's failure to grasp the fundamental concepts of building technology and basic physics required to assemble the diverse elements and materials, so they will be and remain watertight. This paper discusses basic concepts of design and how to assemble materials. It includes active and passive methods of water management, basic axioms to be followed in designing and guidance in detailing to prevent water infiltration and condensation. The material is arranged under the categories of waterproofing, cladding, roofing and condensation. It is presented in the form of a checklist of what to do and what to avoid.
\end{abstract}

Journal of Building Appraisal (2007) 2, 275-281. doi:10.1057/palgrave.jba.2950052

\section{Keywords:}

design, water management, water proofing, building envelope, cladding, roofing

\section{INTRODUCTION}

According to a poll of the membership of the CIB Commission W86 on Building Pathology, the most predominant problems of building pathology are water related. Many of these problems are created on the drawing board where design details are flawed, inviting rather than repelling water infiltration. As a practicing architect for more than 50 years and a consultant for the last 30 , the author has reviewed thousands of details prepared by over a hundred architects throughout the United States. This paper was developed after years of reviewing the same design errors repeated in different offices by different designers. It is a checklist of what to do and what not to do, which will help the designer avoid the most common water-related problems. It represents the author's practice rather than rules to be followed indiscriminately. 


\section{Axioms}

- It is better to eliminate a problem than to spend time trying to solve it. Any detail that is complicated is probably inherently wrong. Re-examine the original premise in order to simplify the detail.

- Any exterior surface that is not vertical is a roof and must be treated as such. Provide flashings under copings and sills. Provide waterproofing under sloped masonry surfaces.

- Do not change materials in the same plane. The resultant joint must rely solely on sealants for its watertight integrity, which does not provide long-term watertight integrity.

- Most building materials do not leak. It is the joints between them that leak. Offset or cover joints for primary leak protection and use a sealant for secondary protection.

- It is better to control or manage the flow of water so that it does no harm to the building than to try and stop it by waterproofing.

\section{Drawings}

- Be responsible for the assembly of materials on the drawings. Do not rely on manufacturer's details of adjoining construction.

- Mentally review the assembly of building elements in the sequence they will be erected or installed. Concrete walls require installation and removal of forms.

- Buildings are erected by people. Allow room for construction personnel to work and for hands and tools used to install fasteners, etc.

- Draw important details at 1-1/2" (1:10) or 3" (1:5) per foot.

- Draw isometrics at corners, at other direction changes and transitions to verify the continuity of elements of elements such as at flashing transitions and window frame corners.

- Locate mechanical, electrical, plumbing and structural components, such as plumbing vents, conduits, drains and equipment supports on architectural roof plans. This facilitates coordination, prevents equipment curbs from blocking drainage valleys and assures that there will be adequate clearance for flashing.

- Allow space for material and erection tolerances; deflection of spandrel beams supporting masonry; deflection of lintels over openings; and thermal- and moistureinduced movement.

\section{Waterproofing}

\section{General}

- Eliminate the need for waterproofing by raising the building above the ground waterline.

- Create passive water and moisture control by proper grading to control surface run-off.

- Extend downspouts to discharge water well away from foundations or connect them to a storm water sewer.

- Where the slab on grade is above the water table, use a vapour retarder in lieu of underslab waterproofing, and provide footing drains and drains under the slab. Extend drains to daylight. Use of pumps is risky. 
- To reduce hydrostatic pressure on framed slabs below grade, provide positive slope to drain. To reduce the hydrostatic pressure on walls, use water permeable panels or backfills with geotextiles. To reduce capillary draw, use granular fill underslabs on grade.

- Raise the top of the foundation not less than $200 \mathrm{~mm}\left(8^{\prime \prime}\right)$ above grade.

- Provide positive drainage sloped 5 per cent over $3 \mathrm{~m}\left(10^{\prime}\right)$ away from foundation walls enclosing occupied or crawl spaces.

- Use positive (wet) side waterproofing where possible. Negative (dry) side is acceptable in pits. Positive side waterproofing controls interior humidity and protects concrete and reinforcing from soil chemicals.

- Select waterproofing systems for resistance to hydrostatic pressure, resealing properties, high elongation, resistance to soil chemicals and history of satisfactory performance - never for reasons of cost or length of guarantee.

- Underslabs on grade above the ground waterline use a 0.25 to $0.37 \mathrm{~mm}$ (10 to $15 \mathrm{mil}$ ) thick polyethylene vapour retarder over $200 \mathrm{~mm}\left(8^{\prime \prime}\right)$ of gravel.

- Use a $25 \mathrm{~mm}\left(1^{\prime \prime}\right)$ thick cement mortar parge coat on masonry foundation walls to receive waterproofing or damp proofing. Parging provides a smooth surface for waterproofing and improves the impermeability of the wall.

- Reinforce all corners and joints in membrane waterproofing with at least one extra ply.

- Do not terminate waterproofing below grade. Extend it at least $200 \mathrm{~mm}\left(8^{\prime \prime}\right)$ above the grade and counter-flash or cover it with insulation, parging or the exterior façade.

- Protect self-adhering modified bitumen waterproofing membranes from sunlight within $36 \mathrm{~h}$ after application. Similarly, protect plastic drainage panels and extruded polystyrene insulation boards. Ultraviolet can cause the membrane to delaminate and the insulation to warp.

- At waterproofed or damp proofed foundations, use granular backfill with geotextiles and low-density expanded polystyrene insulation boards, rather than plastic drainage panels. Insulation boards provide protection and will shear during backfill rather than displace the membrane. The sharp edges of displaced panels can penetrate or displace waterproofing.

\section{Plazas and suspended slabs below grade}

- Install membranes directly on suspended slabs and cover them with insulation, rather than install the insulation over the membrane. This reduces the potential for condensation.

- Install waterproofing on horizontal surfaces that are sloped not less than 1 per cent to internal drains or off the edge of the slab.

- Use gravel, sand or drainage panels over the membrane to permit water drainage.

- Use two-level drains in plazas with the wearing surface inlet separated from the drain body in the structural slab. This will prevent damage from differential movement between the two. Wearing courses respond to thermally induced movement at a greater magnitude than the underlying insulated slabs and can shear the drainpipe or rupture the flashing.

- Provide expansion joints in plazas and roofs aligned with structural expansion joints. Support membranes with tubes 150 per cent wider than the joint. Provide continuous hammocks under the tube to act as a vapour retarder and bitumen stop.

- Space expansion joints in plaza wearing surfaces not over $6 \mathrm{~m}\left(18^{\prime}\right)$ o.c. each way. 
- Provide gutters under expansion joints in elevated slabs above sensitive occupancies.

- Provide curbs to raise expansion joint covers and flashings $40 \mathrm{~mm}\left(1-1 / 2^{\prime \prime}\right)$ above waterproofing. Extend flashing $200 \mathrm{~mm}\left(8^{\prime \prime}\right)$ above curb.

- Do not interrupt plaza waterproofing with planters or architectural elements. Continue the waterproofing under these items. Waterproof the planters independently of the plaza.

- Cover the membrane/insulation/drainage system with an $80 \mathrm{~mm}$ (3") concrete slab to protect it from backfill or the installation of the wearing surface. A slab is critical where landscaping is to be installed, because it protects the membrane from roof intrusion and digging implements.

\section{Cladding}

\section{Masonry: General}

- Use cavity walls for masonry construction with a minimum $50 \mathrm{~mm}\left(2^{\prime \prime}\right)$ wide cavity. Better use rain screens that provide some pressure equalisation, that is weep holes combines with ventilation holes under shelf angles and vertical air barriers to control air flow.

- Provide drips at all horizontal surfaces such as coping overhangs, soffits and heads at copings.

- Avoid using split-faced or ribbed concrete masonry units unless they are in a cavity/rain screen construction.

- Do not seal masonry parapets with roofing or other vapour impermeable materials.

- Provide expansion joints within 1,200 mm (48") of masonry parapet corners. This will reduce the potential for parapets to bend and crack under temperature and moisture gradients.

\section{Stone}

- Use sealants rather than mortar in joints of cut stone, both horizontal and vertical.

- Where the face of masonry copings is flush with the wall and flashings do not project, rake out and caulk the bed joint. Differential movement between the coping and the masonry parapet will cause mortar bed joints to crack and admit water.

- Use sealants and backer rods, rather than mortar at end joints of stone copings.

- Select stones with low absorption where they are in contact with earth. Most granites are suitable. Limestone and other absorbent stones will allow rising damp and snow drifts to stain the stone and cause spalling in freeze thaw areas.

\section{Mortar}

- Tool mortar joints concave or weathered. Avoid raked joints.

- Use the softest mortar consistent with the structural requirements. Hard Portland cement-rich mortars shrink and crack and may cause bricks to spall.

- Avoid additives in mortar. They rarely contribute to the water resistance of the mortar and may inhibit bond. 


\section{Concrete}

- Fabricate precast concrete panels with two-stage joints on both horizontal and vertical edges for pressure equalisation.

- Provide flat surfaces at perimeters of exposed aggregate panels to facilitate caulking.

\section{Stucco}

- Use corner lath, not corner beads to avoid cracking. Use drips screeds, not J-moldings at the bottom of stucco panels.

- Install stucco on furred lath rather than directly on wood or masonry substrates. Furred stucco over an air barrier is an excellent rain screen.

- Do not use stucco or polymer modified cementitious coatings (EIFS) on sills, copings and similar surfaces that are sloped less than $30^{\circ}$. Limit the depth to $100 \mathrm{~mm}\left(4^{\prime \prime}\right)$.

\section{Wall flashing}

- Provide a water management system of flashing and weep holes in masonry cavity walls.

- On the drawings, indicate the cores in bricks or cells in hollow brick and concrete masonry units where flashing occurs. This will avoid terminating flashings over voids in the masonry course below.

- Use solid, rather than hollow bricks under flashings.

- Provide throughwall flashing in masonry walls wherever the cavity or the collar joint is interrupted.

- Provide flashing at the base of all walls, between the foundation and masonry or wood sills to prevent rising damp.

- Use receivers for cap flashing in masonry-rising walls and parapets. This will facilitate the removal and replacement of flashing during re-roofing and will enable the roofing trade to install the cap flashing after the masons have completed the parapet or walls.

- Do not use sawed reglets to receive flashing in masonry or concrete walls; in masonry, horizontal legs should extend at least one wythe deep. Use surface-mounted cap flashing on concrete walls. The ends of metal reglets are often misaligned or do not butt. Sawed reglets are often terminated short of internal corners.

- Step flashing through walls. Extend throughwall flashing beyond wall face and turn down at a $45^{\circ}$ angle or configure flashing to preclude masonry-to-masonry caulking.

- Avoid PVC for flexible flashing. When exposed to heat and UV it will embrittle and crack. Flexible flashing will sag into the cells of hollow masonry units and wall cavities from plastic flow and the weight of mortar.

- Use modified bitumen, EPDM or polyolefin for through wall flexible flashing. Terminate on $100 \mathrm{~mm}\left(4^{\prime \prime}\right)$ stainless steel or 1cc to project beyond the face of the wall.

- Provide weep holes at all concealed flashings. In back-drained and ventilated-rain screens, provide weep holes at both the top and bottom of shelf angles to provide pressure equalisation. For weep holes, use $10 \mathrm{~mm}\left(3 / 8^{\prime \prime}\right)$ diameter oiled cords, which are withdrawn after mortar sets. Alternately, leave head joints open, cover with louvered metal units or fill with stainless steel wood to prevent the entrance of insects and winddriven rain. Avoid plastic weep tubes, they reduce the opening and clog with salts.

- Turn up flashing at window sills, thresholds and loose lintels $50 \mathrm{~mm}\left(2^{\prime \prime}\right)$ at ends to form a pan. In masonry walls turn up into the first head joint beyond the masonry opening. 


\section{Openings, windows and doors}

- Use double hung or turn-tilt windows for greatest storm resistance.

- Avoid sliding doors and windows in walls over $10 \mathrm{~m}\left(30^{\circ}\right)$ above the ground in high wind locations or use a $75 \mathrm{~mm}\left(3^{\prime}\right)$ high barrier on the interior of the sill.

- Carry flashing under sliding door sills $100 \mathrm{~mm}\left(4^{\prime}\right)$ up behind jambs.

- Raise door thresholds and windowsills $200 \mathrm{~mm}\left(8^{\prime}\right)$ above low slope roofs and plazas.

- Extend masonry sills beyond opening to outer edge of jamb trim or $100 \mathrm{~mm}$ (4') on brick walls. Provide an integral lip on the inboard edge of windowsills.

- Avoid through joints between openings and windows or doors sealed only with caulking. Offset frames from walls.

- Require metal window frames to be equipped with flanges at the head to provide a stop for backer rods and sealant.

- Provide for drainage under insulated glass units in metal sash and in large wood sash.

- Maintain continuity of weatherstripping on all four sides of windows and doors. Particularly check horizontal sliding units for weatherstripping continuity at the juncture of meeting stiles and sills.

\section{Sealants}

- Sealant joints should be minimum $10 \mathrm{~mm}\left(3 / 8^{\prime \prime}\right)$ wide. Allowing for joint width tolerances, $13 \mathrm{~mm}\left(1 / 2^{\prime \prime}\right)$ is preferred.

- Use butyl, not elastomeric sealants for sealing lapped metal-to-metal surfaces.

- Avoid coved sealant configurations. Use 1/4 round backer rods or bond breaker tape and convex sealant bead.

- Be sure the element to be sealed is thick enough to accept a backer rod and sealant.

\section{Roofs}

\section{Low sloped roofs}

- Aggregate surfaced conventional built-up roofs are preferable to smooth surfaced. They are stiffer, resist fluttering, traffic and abuse.

- Raise expansion joints and curbs $200 \mathrm{~mm}\left(8^{\prime}\right)$ above the roof.

- At penetrations, raise base flashing above the plane of the roof with tapered edge strips.

- Provide enclosed curbs rather than dunnage for roof top-mounted equipment.

- Leave sufficient space, $200-300 \mathrm{~mm}\left(18^{\prime}-12^{\prime}\right)$, between roof penetrations and between penetrations and vertical surfaces so that they can be flashed.

- Do not build metal into built-up roofing or modified bitumen roofs. Install heavy-gauge metal edge strips and gravel stops on top of the membrane.

- Avoid pitch pockets. Provide hoods at ganged pipes and conduits. Flash other pipes with two-piece lead or copper or use modified bitumen. EPDM, etc, with drawbands at top.

- Avoid mounting railings on parapet copings. Mount them on the interior face with brackets. If posts must be mounted on masonry copings, use a metal sleeve soldered to metal flashing under coping.

- Provide expansion joints for base flashing where parapets and walls are supported independently of roof decks. 


\section{Steep roofs}

- Carry chimney cap flashing stepped through to the flue.

- In freezing climates, use self-adhering modified bitumen sheets at eaves under shingle, tile and slate roofs. Carry $600 \mathrm{~mm}\left(24^{\prime}\right)$ inside wall line. Use heat resisting type under metal roofs or gutters where high temperatures can cause bitumen flow or bonding.

\section{Drainage}

- Slope roofs by minimum 2 per cent. Settlement, construction tolerances and creep can reduce slopes of 1 per cent to zero.

- On low-slope wood roof decks, which are insulated below, use sheet metal drains rather than cast iron drains. The thickness of cast iron drain flanges plus lead flashing and stripping creates dams and ponding around the drains. Alternately, provide wood or metal sumps to receive cast iron drains.

- Offset the drain riser below the drain to absorb vertical movement. This is particularly important with PVC pipe.

- In low-slope roofs with parapets or high curbs, provide overflow drain systems or overflow scuppers $50-100 \mathrm{~mm}$ (2" to 4") above the roof.

- Avoid built-in-gutters inside the wall line. Where they are used, provide an EPDM liner under the gutter and provide for it to drain independently.

- Provide scuppers to built-in-gutters that are located inside the wall line to allow for overflow when the drains are clogged by leaves and debris.

- Avoid loose-locked metal seams below the high waterline of built-in-gutters. They are not watertight.

- Outboard edge of hung gutters should be $25 \mathrm{~mm}$ (1") below the eave to assure that gutter overflow will not back up under the roofing.

\section{Condensation}

- Provide a vapour retarder on the warm side of the building envelope in cold climates where high internal relative humidity is expected. For example, swimming pools, kitchens, auditoriums, computer roofs and art galleries.

- Positive ventilation in attics and crawl spaces will control condensation better than vapour retarders only.

- Select each component on the wall construction to be increasingly vapour permeable from the vapour retarder outward. Note that masonry and plywood have low permeance.

- To ensure the integrity of vapour retarder, detail terminations at transitions between the wall and roof or ceiling, at opening and at penetrations. A critical air and vapour bridge is between a roof and the cavity wall below where vapour may migrate into eaves and parapets. 